\title{
Getting into the Club: Existence and Availability of Mentoring for Tenured Librarians in Academic Libraries
}

\author{
Juliann Couture, Jennie Gerke, and Jennifer Knievel
}

\begin{abstract}
Great attention has been devoted to mentoring for early-career librarians, but little has been paid to the post-tenure experience of academic librarians. Researchers sought to understand the mentoring experiences and barriers to promotion for academic librarians who hold faculty status at public R1 institutions. Surveys sent to tenured academic librarians at 40 institutions invited them to share their experiences with post-tenure mentoring, promotion, and professional development. The study suggests that few structured mentoring programs exist for post-tenure faculty librarians. Additionally, results suggest that five factors influence intent to seek promotion: financial, political, workload, work/life balance, and process/procedural.
\end{abstract}

\section{Introduction}

Librarians have, in a variety of venues, embraced the importance of mentoring for new professionals but nevertheless have largely ignored the role it plays in the success of seasoned or midcareer librarians. For those who hold tenure-track faculty status, what are the support mechanisms in place to motivate and enable them to pursue promotion to the highest ranks available? Mentoring for faculty in all academic areas is key to the promotion and tenure of new professionals, and it has received significant attention in the literature. ${ }^{1}$ While not all librarians hold faculty status, mentoring holds similar importance to the success of new librarians. ${ }^{2}$ Structured mentoring programs can increase access to guidance and support for women and people of color, improve retention, and strengthen professional success. ${ }^{3}$ However, mentoring for new professionals is only the first step. The importance of mentoring extends to midcareer professionals for many of the same reasons: improved professional success and retention, as well as equitable access to professional guidance for women and people of color. Mentoring takes many forms and can be informal or formal in its structure. Informal mentoring can occur through friendship, collegiality, teaching, or any informal means. Formal mentoring programs are structured, assigned, and evaluated by a group or organization, including the traditional senior/junior dyad, group mentoring, and peer mentoring.

\footnotetext{
*Juliann Couture is Head, William M. White Business Library and Assistant Professor at University of Colorado Boulder Libraries; email: juliann.couture@colorado.edu. Jennie Gerke is Associate Dean of Libraries and Associate Professor at University of Colorado Boulder Libraries; email: jennie.gerke@colorado.edu. Jennifer Knievel is Director of Arts $\mathcal{E}$ Humanities and Associate Professor at University of Colorado Boulder Libraries; email: jennifer. knievel@colorado.edu. (2020 Juliann Couture, Jennie Gerke, and Jennifer Knievel, Attribution-NonCommercial (https://creativecommons.org/licenses/by-nc/4.0/) CC BY-NC.
} 
The purpose of this study is to examine and understand the role of mentoring, both formal and informal, for tenured librarians who might consider pursuing promotion to the rank of full professor. The authors surveyed tenured librarians from public R1 universities (doctoral universities with very high research activity) in the United States to gain insight into the existence of mentors, availability of mentoring programs for tenured librarians, and the intentions of tenured librarians to pursue promotion to full professor. The results of the survey suggest that women are less likely than men to plan to pursue promotion but that mentoring has more of an influence on whether or not women pursue promotion than men. Additionally, extremely unclear guidelines discourage people from pursuing promotion. Survey responses suggest that five main factors influence the intention of librarians to seek promotion to full professor: financial, political, workload, work/life, and procedure/process. The study shows that librarians in institutions with mentoring programs are more likely to pursue promotion, whether or not they participate in the mentoring program. Results also suggest that librarians who have already been promoted to full professor have fewer informal mentors.

\section{Literature Review}

Research demonstrates that many factors influence the success of faculty and librarians, including access to mentoring, gender, and the presence of other potential barriers.

\section{Mentoring in Academic Libraries}

There are many examples in the literature of mentoring programs in academic libraries. Overwhelmingly, these programs are aimed at new librarians or those in the early stages of a tenurestream position. ${ }^{4}$ In some cases, the mentoring program is used to onboard new employees with the primary intent to learn about the organizational culture and is only for a limited period of time. ${ }^{5}$ Programs also vary in purpose based on the role and rank academic librarians hold at their respective campuses, since those can range from full faculty status to staff member with many variations in between. In ARL institutions, mentoring is highly prioritized as a main mechanism of support for librarians both in those that grant tenure and those that do not. ${ }^{6}$

Mentoring in academic libraries can come in many forms. Peer mentoring was identified as a recent trend for creating a supportive environment for early-career academic librarians but is limited in its ability to provide advice and guidance related to tenure and promotion. ${ }^{7}$ While the traditional dyad model of "one protégé, one mentor" is common, ${ }^{8}$ other models emerge such as one protégé with two or more mentors, ${ }^{9}$ a group of protégées with one mentor, ${ }^{10}$ and many protégées/many mentors. ${ }^{11}$ Each of these models provide varying benefits based on the needs of the local institution.

As Kuyper-Rushing notes, the existence of a formal mentoring program ensures that people who might otherwise not have access to mentoring experience the associated benefits, such as career satisfaction and a sense of belonging. ${ }^{12}$ Targeted mentoring programs for minority librarians can send the message that the problem is with the librarian of color and be viewed as reme-

dial or contributing to the perception that people of color do not belong in academic libraries. ${ }^{13}$ Damasco and Hodges found that mentoring overall is important for librarians of color since they often reported feeling cut off from access to professional networks and guidance, factors that alleviate a sense of isolation and can support career growth. Additionally, most mentoring aimed at librarians of color is centered on recruitment and retention within the library profession, with little effort being aimed at leadership development and career advancement. ${ }^{14}$ 
Overall, there is a gap in the literature around supporting academic librarians later in their careers, either centered on the pursuit of promotion to full professor or leadership development. Few mentoring programs in academic libraries are aimed at post-tenure or midcareer librarians. ${ }^{15}$ One program that specifically mentions a tier for post-tenure librarians interested in career development and promotion in rank had no librarians elect to participate. ${ }^{16}$ Another program mentions the availability of a group mentoring program for those interested in pursuing promotion to full professor but with limited details on the use and evaluation of this group. ${ }^{17}$ Examinations of post-tenure productivity of academic librarians highlights barriers such as significant shifts in job duties and tensions between service and scholarship. ${ }^{18}$

\section{Mentoring for Academic Faculty}

Mentoring for success of faculty in academia generally for both career satisfaction and psychosocial benefits is well documented. ${ }^{19}$ While early literature focuses heavily on mentoring graduate students and early career faculty, over time there has been a shift to understanding that faculty need mentors for different stages of their careers, and that the need for mentoring does not end when one is awarded tenure. ${ }^{20}$ Further research demonstrates a dip in professional satisfaction and sense of purpose among recently tenured faculty. ${ }^{21}$ Mathews lays out the benefits of mentoring to an organization that includes improved networks, a greater understanding of organizational culture and value, and increased self-confidence and job satisfaction..$^{22}$ The benefits of mentoring are well documented, yet many of the discussions on who needs mentoring and what mentoring should look like is often limited in scope.

While many of these explorations focus on the traditional definition of mentoring where one senior mentor works with one protégé, there are also examples of mentoring models employed to cast a wider net in thinking about how to support faculty throughout their careers. Buch, Huet, Rorrer, and Roberson describe a mentoring program that combines the traditional model of vertical dyad with peer mentoring with other protégés at the rank of associate professor and found that, when associate professors reported having a mentor, they were significantly more likely to perceive that there were incentives in place for seeking promotion and that criteria were clear. ${ }^{23}$ Wasburn outlines a strategic collaboration model of mentoring that groups protégés with senior mentors and aims to alleviate the mentoring barrier of being identified by a senior colleague. ${ }^{24}$ Additionally, Wasburn found that senior colleagues reported benefits from this model, mostly in gaining knowledge and exposure to new perspectives.

During the past decade, there has been a shift from focusing on the traditional notion of junior/senior dyad mentoring to an understanding that one will need multiple mentors throughout their career. Peluchette and Jeanquart found that, for those in the middle career stage, faculty members with multiple mentors were more productive than those with only one mentor or with no mentors. ${ }^{25}$ Van Emmerik identifies mentoring constellations as positively relating to increased job satisfaction, career satisfaction, and being an important tool when faculty are faced with adverse work conditions. ${ }^{26}$ The literature on mentoring points to greater satisfaction and success for faculty who have access to a network of mentors that provide support for a range of issues. However, O'Meara and Stromquist found that, while peer networks provide women faculty with agency and support for career growth and satisfaction, it was limited in its ability to bring about change at departmental or organizational levels. ${ }^{27}$ 


\section{Role of Gender in Seeking Promotion}

An area of increasing exploration in academia generally centers on understanding the barriers to faculty seeking promotion to full professor. ${ }^{28}$ One theme that has emerged in these examinations is the role of gender as a factor in pursuing the highest rank. In a survey of its membership, the Modern Language Association (MLA) identified a lack of clarity around procedures, no defined timeline, gendered expectations, and racial bias as barriers to pursuing promotion to full professor. When it comes to teaching and service requirements, the MLA survey found that this "essential work of the university feels like a mistake or even a self-defeating behavior" for those at the rank of associate. ${ }^{29}$ For Gardner and Blackstone, a deeper understanding of barriers to promotion found that, while the system is often thought of a meritocracy, it is one that is based on criteria that can be applied in gendered or racialized ways. ${ }^{30}$

Existing research into barriers to promotion to full professor focus on gender inequity, without an in-depth exploration of intersections of gender with race/ethnicity or other identities. Geisler, Kaminski, and Berkley found that women were 2.3 times less likely to be promoted than men. ${ }^{31}$ While this documentation of gender discrepancies in promotions inspired women at that institution to pursue promotion, continued study found additional structural issues persisted, such as lack of diversity hires at senior levels and issues with the pipeline of candidates for faculty positions.

\section{Barriers to Promotion}

Understanding why associate professors are not pursuing promotion leads to recommendations for reducing barriers and promoting equity. Common suggestions are to provide mentoring, particularly support for developing mentoring networks. ${ }^{32}$ Other suggestions include providing clear promotion guidelines; guidance in working with department chairs to balance research, teaching, and service; faculty development programs; and structural support for conducting career planning. ${ }^{33}$ One influential factor is what Awando et al. identify as social persuasion, when colleagues or department heads encourage associate professors to pursue promotion. ${ }^{34}$ The act of having another person invite one to consider pursuing promotion is a recurring theme of reducing barriers for associate professors. However, as indicated by Geisler, Kaminski, and Berkley, it is important to ensure that this is done in an equitable way rather than perpetuating the promotion primarily of those who fit stereotyped expectations for full professors, particularly white men. ${ }^{35}$ Overall, the suggestions for reducing barriers for associate professors to pursue promotion to full professor vary by institution and encourage structural, institutional support rather than simply asking the individuals to create solutions.

\section{Method}

To create a data set of individuals in similar institutions, the authors focused this research on public R1 universities, which are more likely to grant faculty status to their librarians than private universities. ${ }^{36}$ The authors began with a list of $81 \mathrm{R} 1$ four-year public universities in the United States. Since verified information regarding whether or not librarians are tenured remains difficult to find, the researchers identified which universities grant librarians faculty status based on information available in their university directories and websites. In cases where that information was inconclusive, the researchers contacted each university individually and asked whether or not their librarians hold faculty status and 
were eligible for tenure. We were able to identify 40 institutions that met our criteria (see appendix A). Some of those universities grant continuing appointments, which are similar to tenure and usually follow a parallel trajectory in the university, though they do not always confer official tenure status. Using those 40 institutions' public directories or direct information from the institutions themselves, the researchers created a list of tenured librarians at each institution. In a few cases, the directories did not indicate librarians' rank. In those instances, the researchers used the addresses of all librarians. The resulting list included 1,009 librarians, most of them tenured, from $40 \mathrm{R} 1$ public universities. Each of those 1,009 librarians received a personal invitation to complete a survey about their experience with post-tenure mentoring, promotion, and professional development (see appendix B).

The survey queried respondents about four main topics:

- Workload distribution, meaning how their work is distributed among librarianship, research, professional service, and other categories.

- Intention to seek promotion to full professor (only asked of associate professors).

- Existence of, and their participation in, formal mentoring or leadership development programs, as well as the availability of mentoring targeted to tenured faculty who might seek promotion to full professor.

- Experiences with informal mentoring, both pre- and post-tenure.

The survey was available for 25 days, during which invitees received two reminders if they had not already responded. Of those invited to participate, 439 respondents began the survey, and 387 individuals completed the survey, for an overall response rate of 38 percent and a survey completion rate of 82 percent. Surveys consisted of a maximum of 47 possible questions, with most respondents answering fewer as a result of question branching. Responses were compiled by the survey software, and the researchers employed spreadsheets and statistical software to analyze the results. Respondents had a maximum of 11 opportunities to submit open-ended comments, though most actually received fewer based on survey branching. The researchers reviewed open-ended comments and identified overall themes that became evident. Participants who expressed interest in further discussions with the researchers received invitations to semistructured interviews, which will be explored in a follow-up analysis.

This study has a few limitations. It does not include non-R1 institutions like community colleges or smaller colleges, many of which offer faculty status to their librarians. Since we do not have access to composite data about the demographic profile of tenured librarians at public institutions, it is not possible to know whether or not the demographic profile of the respondent pool is representative of the larger body of invitees. However, we believe the robust response rate improves the likelihood that the sample is of sufficient size to represent the overall pool.

The authors also included a section in the survey that attempted to determine how tenure was evaluated by percentages of breakdown within categories. For example, an institution might break down workload by librarianship, research, and service or have additional categories for leadership and other categories. In attempting to analyze the data, it became clear that the way different institutions approach this topic varies so widely that the question was largely impossible for the respondents to answer. Therefore, we are unable to draw any conclusions from these questions. 


\section{Results and Discussion}

\section{Demographics}

Library demographics are available from a variety of sources, but none provide demographics based on academic rank. Two data sources provide potentially relevant demographic data: the American Library Association (ALA), focusing on academic libraries using 2009-2010 American Community Survey data, and the Association of Research Libraries (ARL) FY 2015-2016 demographic data. The ARL data set does not represent an exact overlap with the survey respondents for this study, since not all institutions represented are members of ARL. ${ }^{37}$

The racial and ethnic makeup of the sample was not as diverse as that of the library profession as a whole, which itself is overwhelmingly white (see table 1). Numerous studies exist that discuss how the library profession becomes less diverse as individuals are promoted. ${ }^{38}$ Since the study analyzes only associate and full professors, it is possible that the lack of diversity at higher ranks in the profession is reflected in the respondent pool. The small number of responses from nonwhite respondents inhibits the ability

TABLE 1 Demographic Distribution by Race

\begin{tabular}{|l|c|c|c|}
\hline \multicolumn{4}{|c|}{ TABLE 1 } \\
Demographic Distribution by Race \\
\hline Race and Ethnicity & $\%$ Survey & $\%$ ALA & \% ARL \\
\hline $\begin{array}{l}\text { American Indian or } \\
\text { Alaskan Native }\end{array}$ & $0.30 \%$ & $0.65 \%$ & $0.40 \%$ \\
\hline Asian & $2.66 \%$ & $6.28 \%$ & $6.80 \%$ \\
\hline Black or African American & $2.07 \%$ & $4.83 \%$ & $4.70 \%$ \\
\hline $\begin{array}{l}\text { Hispanic or Latinx or } \\
\text { Spanish Origin }\end{array}$ & $2.37 \%$ & $1.53 \%$ & $3.00 \%$ \\
\hline Two or more chosen & $0.30 \%$ & $1.07 \%$ & N/A \\
\hline Prefer not to disclose & $1.78 \%$ & N/A & N/A \\
\hline White or Caucasian & $90.53 \%$ & $85.65 \%$ & $85.10 \%$ \\
\hline
\end{tabular}
of the authors to draw generalizable conclusions from our data around race and ethnicity.

\begin{tabular}{|l|c|c|c|}
\hline \multicolumn{4}{|c|}{ TABLE 2 } \\
Demographic Distribution by Gender \\
\hline Gender & $\%$ Survey & $\%$ ALA & $\%$ ARL \\
\hline Men & $29.29 \%$ & $30.12 \%$ & $36.60 \%$ \\
\hline Prefer not to disclose & $1.18 \%$ & N/A & N/A \\
\hline Women & $69.23 \%$ & $69.87 \%$ & $63.40 \%$ \\
\hline Cisgender* & $0.30 \%$ & N/A & N/A \\
\hline *Self-identified by 1 respondent. \\
\hline
\end{tabular}

Unlike the race and ethnicity data, the gender demographic of the respondent pool closely matches overall percentages in the data pool and thus supports drawing conclusions related to gender (see table 2).

The Department of Education provides data on the breakdown of academic faculty across all disciplines by rank, race, ethnicity, and gender ${ }^{39}$ (see table 3). In

\begin{tabular}{|l|c|c|c|c|c|c|}
\hline \multicolumn{7}{|c|}{ TABLE 3 } \\
\hline Academic Rank & $\begin{array}{c}\text { Survey } \\
\text { Respondents }\end{array}$ & $\begin{array}{c}\text { All } \\
\text { Faculty* }\end{array}$ & $\begin{array}{c}\text { Women Survey } \\
\text { Respondents }\end{array}$ & $\begin{array}{c}\text { All Women } \\
\text { Faculty* }\end{array}$ & $\begin{array}{c}\text { Men Survey } \\
\text { Respondents }\end{array}$ & $\begin{array}{c}\text { All Men } \\
\text { Faculty* }\end{array}$ \\
\hline $\begin{array}{l}\text { Associate Professor/ } \\
\text { Librarian or equivalent }\end{array}$ & $64.79 \%$ & $53.68 \%$ & $65.38 \%$ & $54.72 \%$ & $64.65 \%$ & $41.12 \%$ \\
\hline $\begin{array}{l}\text { Full Professor/ } \\
\text { Librarian or equivalent }\end{array}$ & $35.21 \%$ & $43.62 \%$ & $34.62 \%$ & $45.28 \%$ & $35.35 \%$ & $58.87 \%$ \\
\hline *Data source: https://nces.ed.gov/programs/digest/d17/tables/dt17_315.20.asp. \\
\hline
\end{tabular}


this analysis, the percentage breakdowns of respondents at each rank is almost the same for libraries faculty based on gender; whereas in the national breakdowns the gender difference between these ranks is more pronounced.

\section{Intention to Seek Promotion}

The survey asked several questions related to the intent of associate professors to seek promotion to full professor.

Of the associate professors, 75 percent $(\mathrm{n}=$ 164) indicated "yes" or "maybe" when asked if they intend to seek promotion to full, suggesting that the majority of librarians currently at the rank of associate are interested in seeking

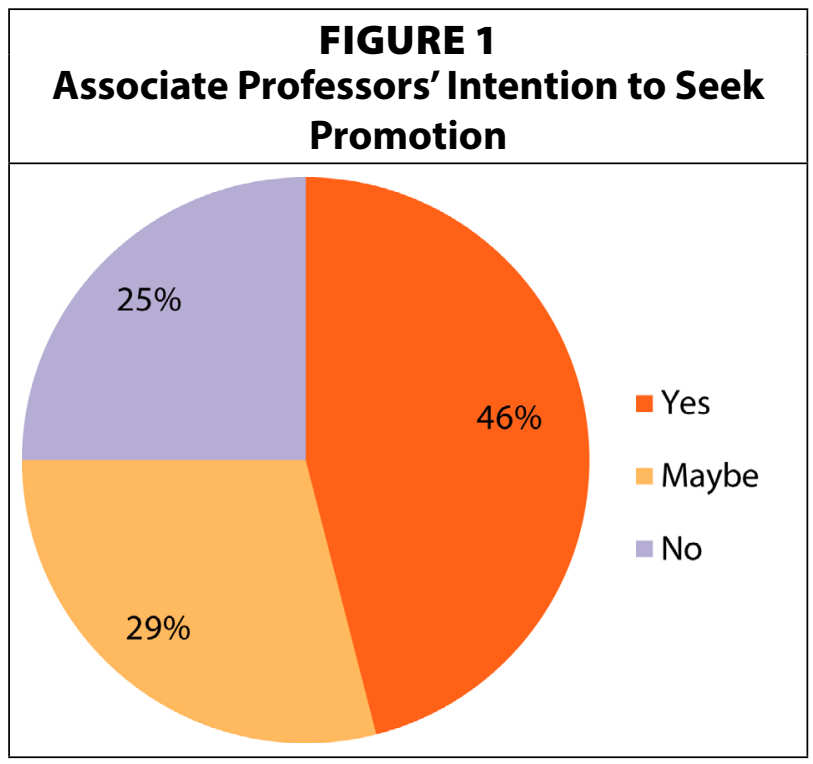
promotion (see figure 1). Almost everyone who expressed an intention to pursue promotion intends to do so within five years.

Regardless of their intent to seek promotion, 219 respondents answered a question about the clarity of the guidelines for promotion. Three-quarters of the respondents described their guidelines as "somewhat clear" or "extremely clear," with only 16 percent of respondents describing their guidelines as somewhat or extremely unclear. The authors anticipated that clarity of guidelines would influence intention to seek promotion, by either encouraging promotion with clear guidelines or discouraging promotion with unclear guidelines. However, there

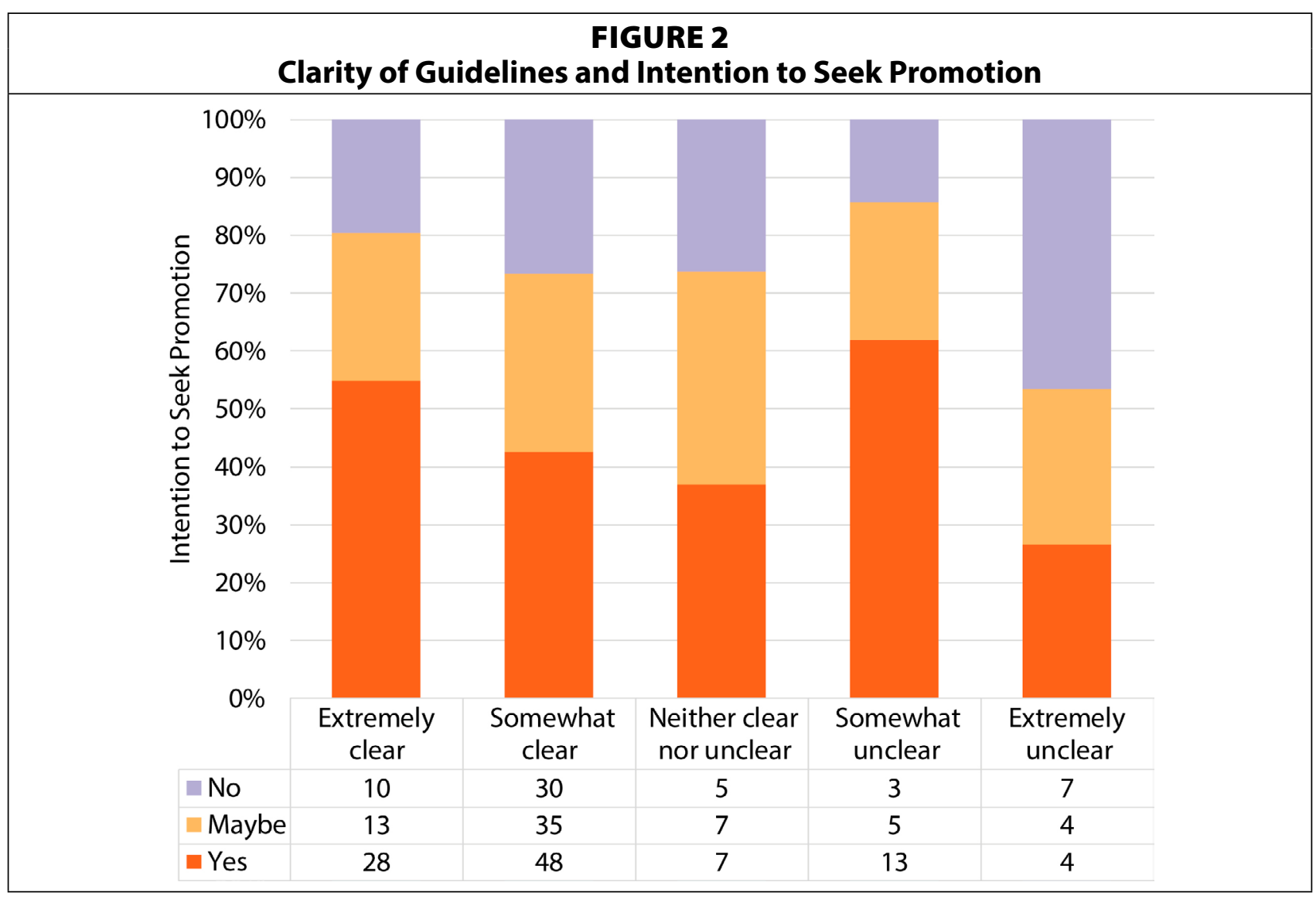


does not appear to be a relationship between whether or not the guidelines are clear and whether or not an individual intends to pursue promotion, except in the case of "extremely unclear" guidelines, which suggests a depressive effect on intention to seek promotion (see figure 2).

Men and women report different percentages of interest in pursuing promotion (see figure 3). Of the men, 81 percent $(\mathrm{n}=$ 52) indicated "yes" or "maybe" to their intent to seek promotion

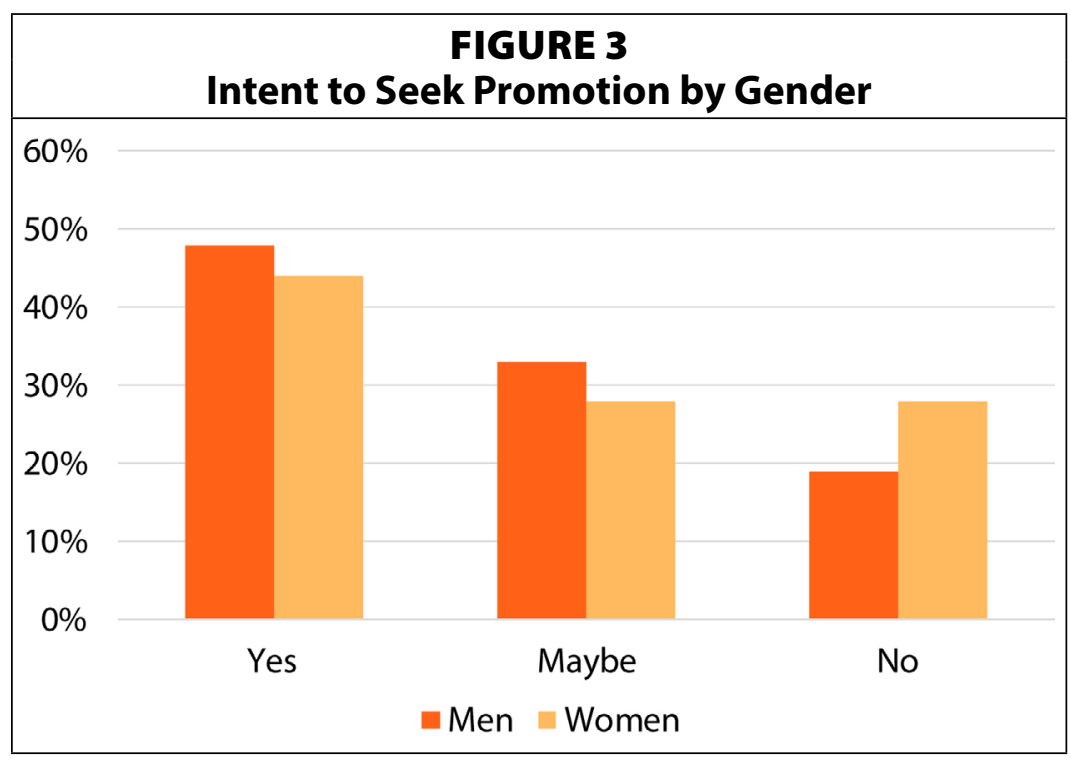
to full professor, while only 72 percent $(\mathrm{n}=111)$ of women indicated "yes" or "maybe" to the same question. This is consistent with other research that finds women are somewhat less likely to pursue promotion to full professor than men. ${ }^{40}$

The survey collected a large volume of comments in the open-ended questions related to the intention to seek promotion. Over five open-ended questions, respondents submitted 1,023 comments. Nearly all survey respondents addressed the rewards of $(\mathrm{n}=310)$, and barriers to (n =303), promotion; additionally, approximately half of survey participants responded to questions related to factors influencing their intent to promote $(n=174)$ or clarity of their guidelines $(n=166)$. It is clear from the high level of engagement with the survey that respondents have strong feelings about the subject of promotion to full professor. A thematic analysis of these responses revealed five major categories into which the majority of the comments sorted.

\section{Financial Factors}

Comments related to money indicated that the financial benefit, or lack thereof, is a strong influence over whether or not associate librarians intend to seek promotion. Numerous commenters indicated that they intended to seek promotion because of a substantial raise, typically described as being $\$ 5,000-\$ 10,000$ or 10 percent or more. On the other hand, some responses indicated that the associated raise was too small to be a motivator. Fewer comments specified what "small" meant, but some suggested that $\$ 5,000$ was insufficiently motivating. Others pointed to financial factors that were not salary, specifically either the increased availability of travel funding or, conversely, the increased expectation of professional travel without additional funding to pay for it. One commenter reasoned, "the only incentive is a raise. I'd spend more of my own money presenting at conferences than I would ever get back in a raise." Another explained, "our professional travel funding is insufficient to cover the professional service that is expected. As librarians we have to make decisions about what to pay from our personal budgets." Several comments indicated that associate professors in their institution have no mechanism for achieving a salary increase in any amount outside of promotion. As one respondent explained, "with budget shortfalls, this is the only way at the present time to obtain a raise, as we currently are not providing merit raises or cost of living raises." While 
salary is clearly an important factor influencing whether or not librarians pursue promotion, it is worth noting that the salary increase does not provide sufficient motivation if it is not large enough to be meaningful.

\section{Political Factors}

Comments related to political factors included numerous descriptions of the existing full professors forming an exclusive "club," described by one respondent as a "good old girls' club," that was uninterested in adding to its numbers. Another example of this sentiment was a librarian who said, "very subjective measures. Turns out to be a popularity vote, not merit vote. Favorites of administrators get preferential treatment for things like service opportunities, what counts for 'research,' things like that." The frequency of these statements suggests this perception of the exclusivity of full professors to be widely held. For example, "the other full librarians/archivists are the barriers... It's all about popularity. The current full librarians/archivists do not want anyone else to be a member of their club. They don't want to encourage new blood or growth." Workplace politics also suggests that, in some institutions, the administration, either in the library or outside it, lacked support for librarians promoting to full professor, or in some cases being on the tenure track at all. One respondent explained, "under the current dean, promotion is impossible. He does not support faculty librarians." In an environment with active opposition to tenure or faculty status for librarians, it might indeed be very difficult to achieve promotion. Several comments described environments in which one cannot seek promotion without being invited to do so, as well as a sense that those invitations were not necessarily objectively distributed. As one respondent noted, "it appears that the administration has designated certain librarians for promotion." Other comments pointed to perceived discrimination based on sex or race. "Gender slant and old-guard vs. new-guard politics. While our overall staff is almost 50/50 gender wise, fulls are about $15 \%$ female." Promotion and tenure are frequently thought of as a meritocracy. However, survey responses suggest that promotion processes are not as objective as librarians might believe and are perceived as highly political processes by those seeking promotion.

\section{Workload Factors}

Comments related to workload were very frequently expressed with a single, oftentimes repeated word, "time," or in some cases "busy." Numerous respondents described their workloads as far too heavy to allow room for research and publication or professional travel, depending on the requirements of the institution. For example, one response articulated this strain stating, "As responsibilities have increased throughout my career, time for publishing is more limited. I feel I owe it to junior faculty to cover for them while they work to achieve tenure. I also am invited to perform more and more service." Several point to a tension between librarianship responsibilities and how research and service feel less central or important: "[It is] difficult to do one's daily work while building a record of achievement sufficient for promotion. Usually, librarians must neglect their regular duties in order to work on projects or service activities." Underlying such comments is a fundamental assumption that research and publication is, in fact, not a real part of one's performance as a librarian. Many respondents pointed to administrative appointment workloads as being too crowded for research. For example, "once you move into management, finding the time to focus on research is extremely difficult." Other comments observed that leadership and management roles are not valued for 
promotion, such as, "greater administrative responsibilities following tenure are not recognized sufficiently as a factor towards obtaining full." Several respondents indicated that reductions in the size of workforce in their libraries, without accompanying reductions in workload, mean that time for research is too difficult to identify. Some respondents voiced a reluctance to pursue promotion because of the inevitable increase to their workload if their promotion was successful, particularly in the form of additional mandatory committees, "disincentives include... increased or mandatory participation on committees needing representation by a full librarian which could take time away from more meaningful contributions to librarianship at national or international levels." Several comments point to burnout by expressing a lack of motivation to contribute the amount of effort needed, "in terms of scholarship, I'm tapped out. After years of maintaining a respectable momentum with research and publication, I've lost my ability to give a damn." Some comments indicate that librarians who have achieved tenure are no longer given the space to pursue research and service, even in places where pretenure librarians are provided with that dedicated support, "Once you are tenured, you have to carve out the time to do it, and generally your workload increases because no one is giving you a 'break' for being tenure-track." Comments broadly suggest that research and publication are thought of as extra work to be squeezed in around the edges of more fundamental librarianship or administrative responsibilities and that often these fundamental responsibilities hold insufficient value in the promotion processes.

\section{Work/Life Balance Factors}

Responses related to work/life balance related in some ways to the workload comments, in that they largely pointed to an absence of sufficient time to pursue research projects. There was a difference in the context of the comments, however, in that they reported that the time pressure originated from an expectation or requirement that pursuing promotion would mean using their personal time to pursue research and publication. One respondent explained, "achieving promotion to full requires maintaining a level of excellence in librarianship and other areas and that is difficult to do when also trying to maintain some level of appropriate work/life balance." Several commenters, pointed to conflicts with parenting or caring for others as a barrier. For example, "motherhood sort of derailed my career aspirations. Glad I only had one kid after being awarded tenure." Another described, "I made the decision to start a family shortly after receiving tenure. As the parent responsible for $90 \%$ of the housework and child care, it is impossible to put in the hours after standard work hours and on weekends that would boost my research productivity which is now required for promotion to full librarian." Other comments described a simple unwillingness to subsume their personal lives into work priorities, since their workplaces are less likely to allow release time for research post-tenure, "I'm already feeling exhausted and I need to do more? When do I get my weekends to be completely free of work?" Another points out that "the near-necessity of working many additional hours for a title and a little money is not a compelling motivation at this juncture." This problem appears across academia; research shows that increasing working hours does improve productivity but consequently decreases job satisfaction. ${ }^{41}$

A high volume of commenters described themselves as too close to retirement for the effort to be worthwhile. Several comments describe the process of achieving tenure as exhausting, and having insufficient motivation to face a similar challenge when it is optional, "I think many librarians on the tenure track at my institution focus all their energies on making tenure 
and promotion to Associate Librarian and at that point stop publishing for several years or sometimes forever." One comment described it as liberating to elect not to pursue promotion, "the process of being promoted to associate professor was very stressful, both mentally and emotionally. I have no intention of going through that again. It feels very liberating to not have a promotion process hanging over my head. I am better at my job by not also having to deal with a promotion process." Interestingly, only a few respondents commented that sabbaticals were possible for them, with some specifying that they are not. The absence of sabbaticals or other dedicated research time might contribute to the sense of unattainable scholarly output. Underlying nearly all of the comments about work/life balance is the assumption that promotion cannot be achieved within the work day, and that devoting one's evenings, weekends, holidays, and other free time is a requirement to obtain the required level of productivity.

\section{Procedural/Process Factors}

Respondents cited a variety of factors related to process or procedures that served as either incentives or barriers to pursuing promotion. In some cases, the process includes an invitation to submit for promotion, which served as incentive to some and a barrier to others, "it is unclear to most in my organization how you are nominated for promotion to full." In other cases, lack of clarity of the process or the guidelines, or a conflict between the guidelines in the libraries as opposed to the campus, served as a barrier: "it is well known that the path to full librarianship is mysterious and black box-y, right down to who serves on the review committee. It's a secret!" Another explains, "I wish our guidelines were more clear. We do not have definitive instructions about constitutes the next steps. We are odds with the teaching faculty on my campus. Teaching faculty have definite guidelines for each promotion step." Some refer to lack of understanding of cases at the university level: "we have had very few librarians go up for Full Professor. As a result, while institutional standards are reasonably clear, we have not had many opportunities to test what 'distinction' looks like in our particular culture and how well our ideas about distinction translate to non-librarian members of our community who review our dossiers." In at least one case, the expected process was to have to apply for promotion at least twice, as described by one response: "multiple full librarians stated to me before I went up for full that they always vote no the first time. It was like an unspoken rule in the library. I didn't understand the reasoning and I still do not understand the reasoning." Some comments suggest that promotion to full is required to attain promotions in leadership roles, either simultaneously or separately. Many respondents specifically called out the lack of mentoring after tenure as a hindrance to promotion, “...there isn't any ongoing mentoring after you achieve P\&T to associate. There isn't anyone cheering you on or prodding you - it really has to come from an intrinsic desire and, from my observation at least, looks very much like an individual, solo effort." Another points out, "we are very good preparing librarians for tenure but very poor at preparing tenured colleagues for promotion." Some comments point out that few people have been promoted, cloaking the process in uncertainty such as the assessment from this commenter: "there is no similar mentorship for those seeking full professor. And there aren't that many people here who' ve done it, so it's really up to the individual to find any mentoring they need." The mystery surrounding the processes and procedures underlying promotion to full professor appears frequently in comments. Providing clarity around processes and expectations is frequently described as an important role of mentors for pretenure faculty, and survey responses point to a similar need at the level of full professor. 


\section{Formal Mentoring and Leadership Development}

While 80.11 percent $(n=270)$ of respondents indicated that their libraries provide formal mentoring, only 30.56 percent $(n=103)$ of respondents' institutions provide formal mentoring and leadership development for people at the rank of associate.

Of the respondents whose libraries offer formal mentoring, 52.53 percent of respondents $(n=52)$ overall participate in this mentoring: 45 percent of men $(n=18)$ participated, whereas 70.83 percent of women $(n=34)$ participated. These results are important in light of the fact that research indicates that offering formal mentoring is particularly beneficial to women and people of color, who are less likely to have consistent access to the benefits of informal mentoring, such as professional networks and higher career satisfaction, than white men. ${ }^{42}$ The most common focus of these formal mentoring programs was promotion to full $(49 \%, n$ $=74)$, followed by leadership development $(26 \%, n=40)$, and other $(24 \%, n=37)$.

Formal mentoring provided by the campus is even less available to individuals at the rank of associate, with only 12.13 percent of individuals $(n=41)$ reporting access to such a program. The percentage of respondents who were unaware of whether such a program existed was much higher at 42.3 percent $(n=143)$, versus 1.48 percent $(n=5)$ within the libraries. The breakdowns were similar in program focus with promotion to full at 46 percent $(n=25)$, leadership development at 35 percent $(n=18)$, and other at 19 percent $(n=10)$.

The majority of individuals overall with access to mentoring participated. However, when broken down by rank, a much higher percentage of full professors participated in mentoring before promotion $(66 \%, \mathrm{n}=35)$ than associates who currently participate in mentoring pro-

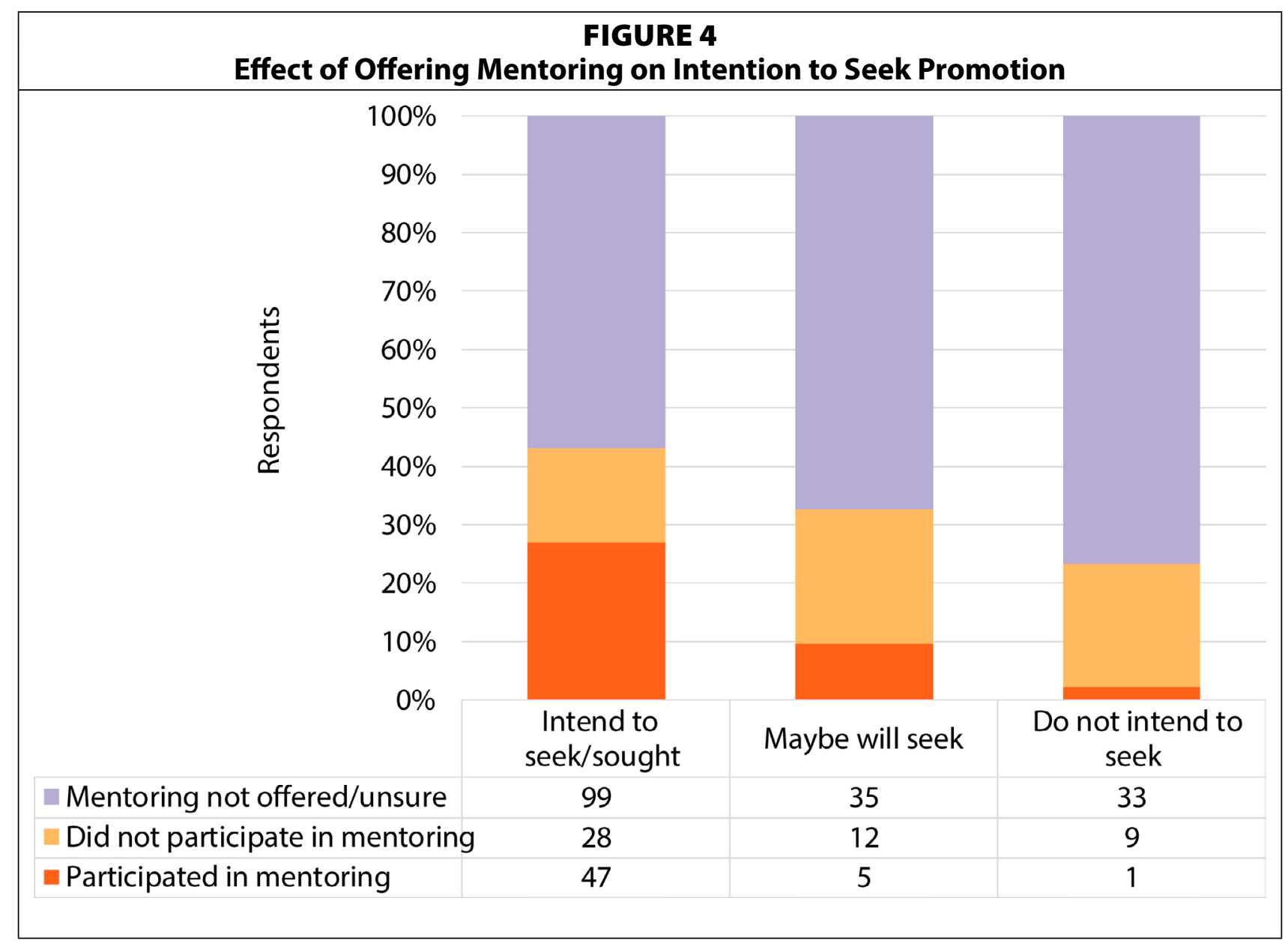


grams $(47 \%, \mathrm{n}=28)$. Therefore, it is useful to investigate the relationship among those who participated and their intention of seeking promotion to full professor.

Figure 4 more clearly indicates that, of those who are offered mentoring and intend to seek or sought promotion, the majority (63\%) participate in mentoring. The simple existence of formal mentoring at the library level, regardless of actual participation, also seems to inspire more individuals to seek or intend to seek promotion ( $74 \%)$. Conversely, when mentoring isn't offered, a much lower percentage of respondents sought or intended to seek promotion (59\%). This suggests that simply by offering a formal mentoring program, libraries may facilitate an environment in which librarians are more likely to pursue promotion to full professor.

\section{Informal Mentoring}

Informal mentoring suffers from a definitional crisis. The authors framed the survey questions on this topic with this statement: "Informal or natural mentoring can occur through friendship, collegiality, teaching, or any informal means." However, it is fairly common for people to have a very narrow mental image of a mentor. Therefore, it is possible that the respondents underreported access to informal mentoring if people in their professional network act as confidant, guide, or some other capacity that might not look like a traditional one-on-one senior mentor.

For respondents at the rank of full professor, 51 percent indicated they do not have someone they consider to be an informal mentor. However, for the same demographic, 66 percent responded that between tenure and promotion to full professor they did have an informal mentor, indicating that, after promotion, fewer full professors continue to have access to mentoring. Some respondents had informal mentors during the time between associate and full, but they now consider themselves to be the ones who act as mentor for others or that those

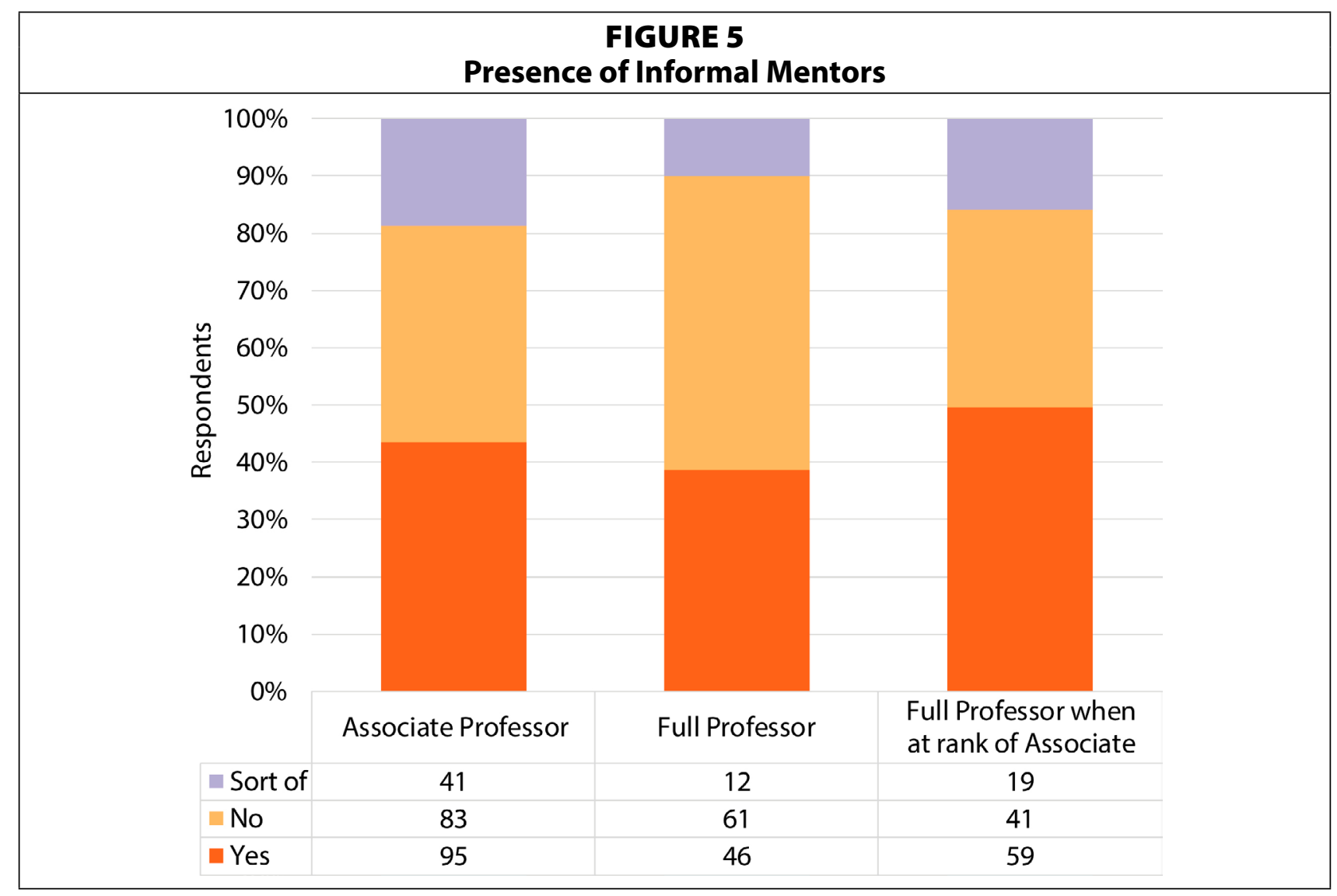


who did mentor them have retired. Responses from those at the rank of associate indicated that 62 percent have someone they considered, or sort of considered, to be an informal mentor, which is close to the percentage of full professors who indicated that they had an informal mentor between tenure and promotion.

Of the associate professors who responded to questions regarding the presence of informal mentors, 51 percent indicated that they intend to seek promotion and have someone they consider or sort of consider to be an informal mentor. The existence of an informal mentoring relationship appears to have a greater influence on whether women pursue promotion to full professor than men (see figures 6 and 7).

For associate professors without an informal mentor, men were more likely to intend to seek promotion than women. Most striking was the difference between associate professors with no informal mentors who said they do not intend to seek promotion: only a quarter $(26 \%)$ of men without informal mentors said "no," while nearly half ( $45 \%)$ of women without informal mentors indicated no plans to pursue promotion.

When asked about how they connected with their informal mentors, the responses were wide-ranging. For some, these informal mentors had once served as formal mentors during their tenure process, or supervisors in early career positions, and continued in a mentoring capacity after the formal time expired. Other connections were formed through professional associations, campus leadership programs, or other work environments. A common refrain was that the person identified an area where they needed support and sought out assistance from others they deemed strong in this area such as providing assistance in putting together promotion materials or seeking guidance in the publishing process. In some cases, respondents noted that they went to full professors at their institution who are in departments outside of

\begin{tabular}{|c|c|c|c|c|}
\hline \multicolumn{5}{|c|}{$\begin{array}{c}\text { FIGURE } 6 \\
\text { Men's Intent to Seek Promotion with/without Informal Mentoring }\end{array}$} \\
\hline \multicolumn{5}{|c|}{$100 \%$} \\
\hline \multicolumn{5}{|c|}{$90 \%$} \\
\hline \multicolumn{5}{|c|}{$80 \%$} \\
\hline \multirow{8}{*}{ 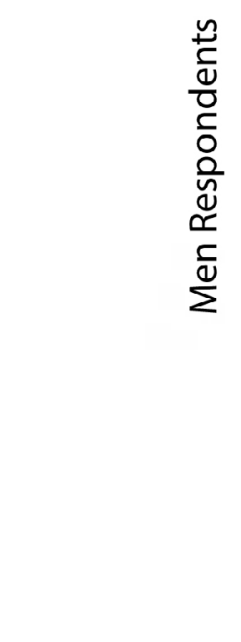 } & $70 \%$ & & & \\
\hline & $60 \%$ & & & \\
\hline & $50 \%$ & & & \\
\hline & $40 \%$ & & & \\
\hline & $30 \%$ & & & \\
\hline & $20 \%$ & & & \\
\hline & $10 \%$ & & & \\
\hline & $0 \%$ & $\begin{array}{l}\text { Have an } \\
\text { informal mentor }\end{array}$ & $\begin{array}{l}\text { Sort of have an } \\
\text { informal mentor }\end{array}$ & $\begin{array}{l}\text { Do not have an } \\
\text { informal mentor }\end{array}$ \\
\hline \multicolumn{2}{|c|}{ Do not intend to seek } & 2 & 1 & 9 \\
\hline \multicolumn{2}{|c|}{ Maybe intend to seek } & 9 & 4 & 8 \\
\hline \multicolumn{2}{|c|}{ Intend to seek } & 10 & 3 & 18 \\
\hline
\end{tabular}




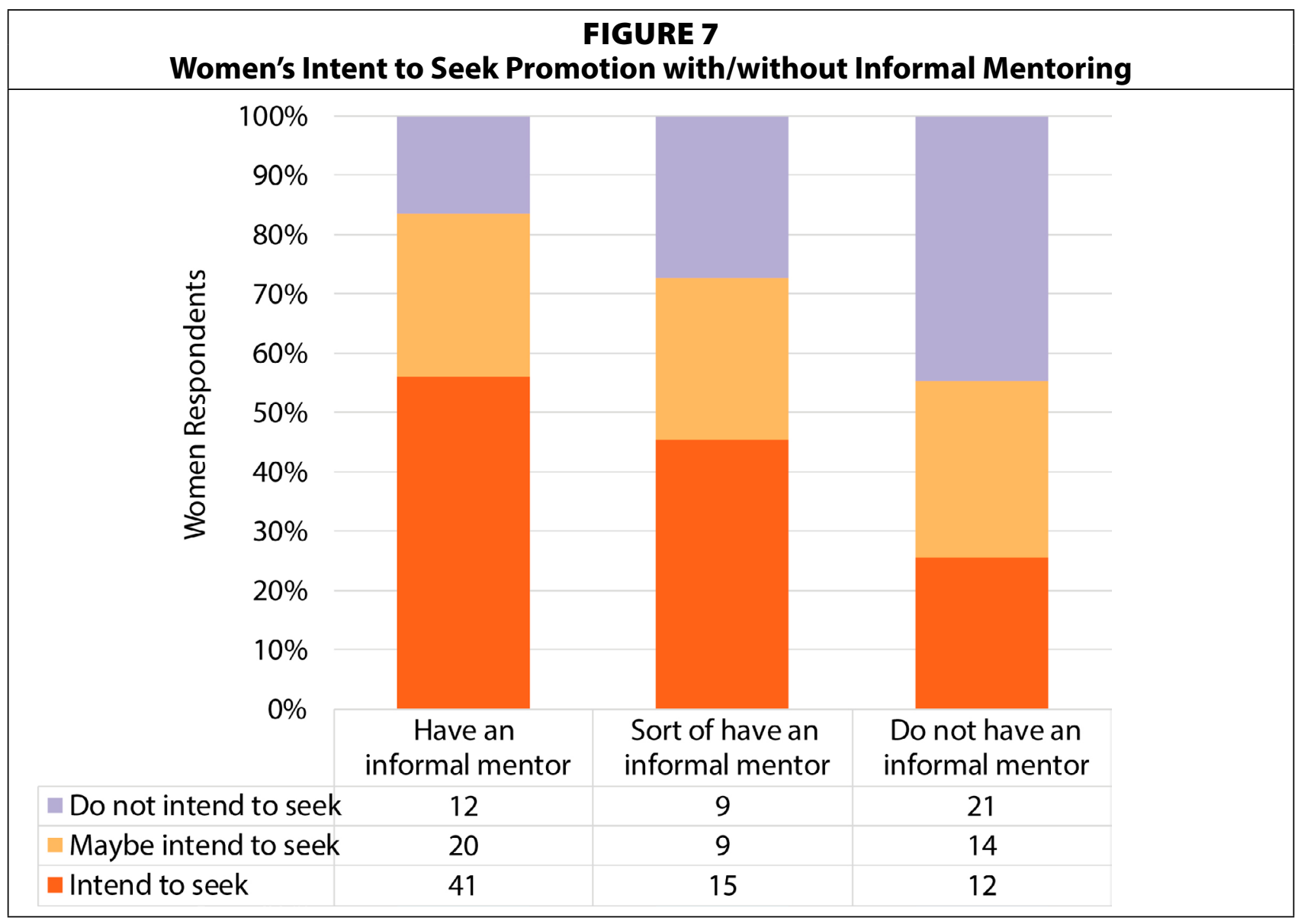

the library for informal mentoring, usually focused on articulating their research agenda and its importance to the library.

Some respondents indicated that informal mentors play an important role in pursuing or intending to pursue promotion to full professor due to what Awando et al. refer to as social persuasion. ${ }^{43}$ This might include: hearing from a colleague, supervisor, or dean that they should consider applying for promotion, or that a committee of full professors reviewed dossiers of associates to provide feedback on who might be ready to seek promotion or what a person might do to better situate themselves for a successful promotion case. One respondent discussed their experience with social persuasion between the time of tenure and promotion to full:

In an informal conversation with a colleague at the rank of professor, he encouraged me to apply for promotion to professor after hearing about my several recent significant international presentations and my recent publications. He encouraged me to meet with other colleagues at the rank of professor at our university to ask them if they thought I was ready for promotion, or if they thought I needed to work more in a particular area. After meeting with five additional colleagues, who all agreed I was ready, I decided to apply for promotion.

Others stressed that trust played an important role in whether or not they sought out informal mentors and, if so, with whom they connected. For one respondent, a person they 
considered an informal mentor was a colleague with whom they could discuss work and other projects but also was "someone I could trust to not divulge any confidential matters to other colleagues." Conversely, others had the opposite experience, in which the people they had considered mentors divulged information they had believed to be confidential.

\section{Further Research}

Following the survey, the authors conducted 18 structured interviews with interested survey participants to gain additional insight into the influences related to promotion for tenured librarians. Results of those interviews will be assessed in further research. Other areas for future investigation include the awkwardness of the fit between tenure and the role and structure of libraries, and the role of mentoring and promotion among non-tenure-track librarians or librarians in other categories of institutions, and the forms of structural support available for librarians interested in promotion and advancement.

\section{Conclusion}

Mentoring clearly influences the long-term success of faculty in many academic areas. While considerable analysis exists of mentoring for new faculty librarians, little attention has been paid to mentoring and career planning for tenured librarians who might pursue promotion to full professor. This study surveyed tenured librarians in R1 Public University Libraries to identify the influences on a faculty librarian's intention to pursue promotion to full professor, as well as the existence of structured mentoring programs available to tenured librarians. The authors found that few libraries offer structured mentoring to tenured librarians; that women are more likely to participate in existing mentoring than men; that men without mentors are more likely to seek promotion than women without mentors; that librarians are largely unaware of whether or not campus programs supporting promotion exist; and that financial, political, workload, work/life, and procedure/process factors influence librarians' intentions to pursue promotion. The results of this analysis show that formal mentoring programs help establish mentoring networks that continue to provide long-term support. Lack of structural support represents a significant barrier to promotion to full professor for faculty librarians. The authors note that library organizations can put in place structural supports, such as targeted mentoring for tenured librarians, that appear to have meaningful influence on the promotion of associate professors. These structures can disrupt the "exclusive club" politics so widely associated with promotion for librarians and improve inclusive access to higher ranks for all tenure-track librarians. 


\section{APPENDIX A. Tenure-Granting Institutions Public R1 Universities}

Note: These universities self-identified as tenure granting. Some of them grant continuing appointment.

1. Clemson University

2. Colorado State University-Fort Collins

3. CUNY Graduate School and University Center

4. Indiana University-Bloomington

5. Iowa State University

6. Kansas State University

7. Louisiana State University and Agricultural \& Mechanical College

8. Michigan State University

9. Ohio State University-Main Campus

10. Oregon State University

11. Pennsylvania State University-Main Campus

12. Purdue University-Main Campus

13. Rutgers University-New Brunswick

14. Stony Brook University

15. SUNY at Albany

16. Texas A \& M University-College Station

17. Texas Tech University

18. The University of Tennessee-Knoxville

19. University at Buffalo

20. University of Alabama at Birmingham

21. University of Arizona

22. University of Arkansas

23. University of Cincinnati-Main Campus

24. University of Colorado Boulder

25. University of Florida

26. University of Hawaii at Manoa

27. University of Illinois at Chicago

28. University of Illinois at Urbana-Champaign

29. University of Kansas

30. University of Kentucky

31. University of Louisville

32. University of Mississippi

33. University of Nebraska-Lincoln

34. University of New Mexico-Main Campus

35. University of Oklahoma-Norman Campus

36. University of South Carolina-Columbia

37. University of Utah

38. University of Washington-Seattle Campus (not classed as faculty)

39. Washington State University

40. Wayne State University 


\section{APPENDIX B. Survey}

What is your current rank?

$\square$ Assistant Professor/Librarian or equivalent

- Associate Professor/Librarian or equivalent

$\square \quad$ Full Professor/Librarian or equivalent

$\square \quad$ None of above

If Assistant or None of above skip all questions.

If Associate:

Years at Rank of Associate Professor/Librarian
$\square \quad 1-2$
$\square \quad 3-5$
6-9
10-14
15+

If Full:

Years at Rank of Full Professor/Librarian
1-2
3-5
$\square \quad 6-9$
ㅁ 10-14
$\square \quad 15+$

Years at rank of Associate Professor/Librarian before promotion to Full Professor/Librarian
ㅁ 1-2
3-5
ㅁ 6-9
10-14
$\square \quad 15+$

All:

Years at current institution
1-5
6-10
11-15
16-20
21-25
25+

\section{All:}

Years in the profession
5-10
11-15
16-20 
21-25

$\square \quad 25+$

I identify my gender as

- Woman

$\square$ Man

$\square$ Trans

Prefer not to disclose

Please specify your race and/or ethnicity (select all that apply)

(Randomize all answers except last one, which should stay last-allow multiple answers)

American Indian or Alaskan Native

$\square$ Asian

$\square$ Black or African American

$\square \quad$ Native Hawaiian or Other Pacific Islander

$\square$ Hispanic or Latinx or Spanish Origin

$\square \quad$ White or Caucasian

$\square$ Prefer not to disclose

Does your current position include supervisory or management responsibilities?

$\square$ Yes

$\square \quad$ No

Please share your workload distribution used for evaluation related to tenure and promotion. Three common categories are provided along with an additional field for other categories your institution uses. For example: $40 \%$ research, $40 \%$ librarianship/teaching, $20 \%$ service

Definitions:

Research: Scholarly and creative work such as publications, presentations, etc.

Librarianship/Teaching: The duties assigned to your position such as reference, instruction, cataloging, data management, etc.

Service: Campus, state, national, or other membership, and participation on committees, task forces, and other professional groups

Research

Librarianship/Teaching

Service

Other

Other

Any additional comments or explanations on workload distribution

If Associate:

Do you intend to seek promotion to full professor/librarian?

$\square$ Yes

$\square \quad$ No

$\square$ Maybe 
If No:

Tell us about why not. (box)

If Maybe:

Tell us what factors might influence whether or not you decide to seek promotion.

If Yes:

How soon do you expect to seek such a promotion?

$\square \quad 1-2$ years
$\square \quad 3-5$ years
$\square \quad 6-9$ years
$\square \quad 10+$ years

Now we would like to ask you about your institutional standards for promotion.

Are there clear guidelines or procedures for promotion to full librarian/professor at your institution?

$\square \quad$ Extremely clear

$\square$ Somewhat clear

$\square \quad$ Neither clear nor unclear

$\square$ Somewhat unclear

$\square \quad$ Extremely unclear

Are there any comments on these guidelines or procedures you would like to share?

What are the rewards, both financial and professional, for pursuing promotion to full?

Are the rewards worth the work?

$\square$ Definitely worth it

$\square$ Mostly worth it

$\square$ Worth it

$\square$ Mostly not worth it

$\square$ Definitely not worth it

What do you perceive as barriers to becoming a full professor/librarian?

Mentoring is a relationship between two or more parties, in which they exchange feedback, wisdom, and technical or life experiences with each other. This relationship can form through formal/structured means or through informal/natural means.

The next few questions focus on formal/structured mentoring where the mentor(s) and mentee(s) are brought together through a defined process.

Does your library have a formal mentoring program?

$\square$ Yes

$\square \quad$ No

$\square$ I don't know/not sure 
If Yes:

Is this formal mentoring available to individuals at the rank of associate?
$\square \quad$ Yes
$\square \quad$ No
I don't know/not sure

If Yes:

What is the purpose of this mentoring? (can select multiples)

$\square \quad$ Leadership development

$\square \quad$ Promotion to full

$\square$ Other

If Available and Associate:

Do you participate?

$\square \quad$ Yes
$\square \quad$ No

If Available and Full:

Did you participate?

$\square \quad$ Yes
$\square \quad$ No

Now we would like to ask you some questions about mentoring at the campus level at your university.

Does your campus have a formal mentoring program at the associate level?
$\square$ Yes
$\square \quad \mathrm{No}$
$\square$ I don't know/not sure

If Yes:

What is the purpose of this mentoring? (can select multiples)

$\square \quad$ Leadership development

$\square \quad$ Promotion to full

$\square$ Other

If Available and Associate:

Do you participate?
$\square \quad$ Yes
$\square \quad \mathrm{No}$

If Available and Full:

Did you participate?

$\square \quad$ Yes

$\square \quad$ No 
Informal or natural mentoring can occur through friendship, collegiality, teaching, or any informal means. The next questions ask about your informal mentoring experience(s).

Do you currently have mentor(s) with whom you connected with through an informal process?

$\square \quad$ Yes

$\square$ No

$\square$ Sort of (please explain)

If Full:

Between the time you received tenure and were promoted to full professor/librarian, did you have any mentor(s) with whom you connected through an informal process?

$\square$ Yes

$\square \mathrm{No}$

$\square \quad$ Sort of (please explain)

If Yes or Sort of:

Tell us how you identified or connected with your mentor(s).

Leadership development is intentional professional development or other learning specifically designed to build leadership or management skills.

Does your library provide workshops or other programming on leadership development?

$\square$ Yes

$\square$ No

․ Sort of

If Yes or Sort of:

Please briefly explain.

Does your campus provide workshops or other programming on leadership development?

$\square$ Yes

$\square$ No

$\square$ Sort of

If Yes or Sort of:

Please briefly explain.

Do you have any final comments you would like to share?

Would you be willing to participate in a 15- to 30-minute discussion with the investigators on mentoring and leadership development? (required)

口 Yes

口 No

$\square \quad$ Maybe, tell me more 
If Yes:

Thank you for considering participating in a 15- to 30-minute discussion with the investigators on mentoring and leadership development! Your survey responses will remain anonymous; your contact information will not be associated with your survey responses in any way. Please provide your contact information:

$\square \quad$ Name

$\square \quad$ Email Address

$\square$ Preferred Pronoun

$\square$ Comments/Questions:

\section{Notes}

1. W. Brad Johnson, On Being a Mentor: A Guide for Higher Education Faculty (Mahwah, NJ: Lawrence Erlbaum Associates, 2007); Pamela Mathews, "Academic Mentoring Enhancing the Use of Scarce Resources," Educational Management E Administration 31, no. 3 (July 1, 2003): 313-34, https://doi.org/10.1177/0263211X03031003007; Joy Van Eck Peluchette and Sandy Jeanquart, "Professionals' Use of Different Mentor Sources at Various Career Stages: Implications for Career Success," Journal of Social Psychology 140, no. 5 (October 2000): 549-64, http://search.proquest.com/docview/199811439?pq-origsite=360link; Peg Boyle and Bob Boice, "Systematic Mentoring for New Faculty Teachers and Graduate Teaching Assistants," Innovative Higher Education 22, no. 3 (March 1, 1998): 157-79, https://doi.org/10.1023/A:1025183225886.

2. Lois Kuyper-Rushing, "A Formal Mentoring Program in a University Library: Components of a Successful Experiment," Journal of Academic Librarianship 27, no. 6 (November 2001): 440, http://search.ebscohost.com/login. aspx?direct=true\&db=aph\&AN=5602703\&site=ehost-live; Jane Stephens et al., "Tenure Support Mechanisms Provided by the Faculty Research Committee at Texas A\&M University Libraries: A Model for Academic Libraries," Library Management 32, no. 8/9 (October 25, 2011): 531-39, https://doi.org/10.1108/01435121111187897; Eileen K. Bosch et al., "The Resource Team Model: An Innovative Mentoring Program for Academic Librarians," New Review of Academic Librarianship 16, no. 1 (April 2010): 57-74, https://doi.org/10.1080/13614530903584305.

3. Peluchette and Jeanquart, "Professionals' Use of Different Mentor Sources at Various Career Stages"; Robert Boice, Advice for New Faculty Members: Nihil Nimus (Boston, MA: Allyn and Bacon, 2009).

4. Diane L. Lorenzetti and Susan E. Powelson, "A Scoping Review of Mentoring Programs for Academic Librarians," Journal of Academic Librarianship 41, no. 2 (March 2015): 186-96, https://doi.org/10.1016/j.acalib.2014.12.001.

5. Maria Taesil Hudson Carpenter et al., "Employee Onboarding: Identification of Best Practices in ACRL Libraries," Library Management 34, no. 3 (February 22, 2013): 200-18, https://doi.org/10.1108/01435121311310897; Bosch et al., "The Resource Team Model."

6. Elizabeth M. Smigielski, Melissa A. Laning, and Caroline M. Daniels, "Funding, Time, and Mentoring: A Study of Research and Publication Support Practices of ARL Member Libraries," Journal of Library Administration 54, no. 4 (May 19, 2014): 261-76, https://doi.org/10.1080/01930826.2014.924309.

7. Lorenzetti and Powelson, "A Scoping Review of Mentoring Programs for Academic Librarians"; Jill Cirasella and Maura A. Smale, "Peers Don't Let Peers Perish: Encouraging Research and Scholarship among Junior Library Faculty," Collaborative Librarianship 3, no. 2 (2011): 98-109, https://digitalcommons.du.edu/collaborativelibrarianship/vol3/iss2/5; Amy F. Fyn, "Peer Group Mentoring Relationships and the Role of Narrative," Journal of Academic Librarianship 39, no. 4 (July 1, 2013): 330-34, https://doi.org/10.1016/j.acalib.2012.11.016.

8. Kuyper-Rushing, "A Formal Mentoring Program in a University Library"; Nikhat Ghouse and Jennifer Church-Duran, "And Mentoring for All: The KU Libraries' Experience," portal: Libraries and the Academy 8, no. 4 (October 2008): 373-86, http://search.proquest.com/docview/216179265?accountid=14503; Catherine Wojewodzki, Linda Stein, and Tommy Richardson, "Formalizing an Informal Process," Technical Services Quarterly 15, no. 3 (January 27, 1998): 1-19, https://doi.org/10.1300/J124v15n03_01.

9. Stephens et al., "Tenure Support Mechanisms Provided by the Faculty Research Committee at Texas A\&M University Libraries"; Bosch et al., "The Resource Team Model."

10. Diana Farmer, Marcia Stockham, and Alice Trussell, "Revitalizing a Mentoring Program for Academic Librarians," College E Research Libraries 70, no. 1 (January 2009): 8-24, http://search.ebscohost.com/login.aspx?d irect=true\&db=aph\&AN=36321152\&site=ehost-live.

11. Jennifer Knievel et al., "Inorganic Is Still Good for You: Building a Structured Group Mentoring Program for Librarians," in Beyond Mentoring, ed. Dawn Lowe-Wincentsen (New York, NY: Elsevier, 2017), 19-38. 
12. Kuyper-Rushing, "A Formal Mentoring Program in a University Library."

13. Ione T. Damasco and Dracine Hodges, "Tenure and Promotion Experiences of Academic Librarians of Color," College \& Research Libraries 73, no. 3 (2012): 279-301, http://crl.acrl.org/content/73/3/279.short.

14. Damasco and Hodges, "Tenure and Promotion Experiences of Academic Librarians of Color."

15. Lorenzetti and Powelson, "A Scoping Review of Mentoring Programs for Academic Librarians."

16. Wojewodzki, Stein, and Richardson, "Formalizing an Informal Process."

17. Knievel et al., "Inorganic Is Still Good for You."

18. Christopher V. Hollister, "An Exploratory Study on Post-Tenure Research Productivity among Academic Librarians," Journal of Academic Librarianship 42, no. 4 (July 2016): 368-81, https://doi.org/10.1016/j.acalib.2016.04.021.

19. Johnson, On Being a Mentor; Boyle and Boice, "Systematic Mentoring for New Faculty Teachers and Graduate Teaching Assistants."

20. Angela Lumpkin, "Follow the Yellow Brick Road to a Successful Professional Career in Higher Education," Educational Forum 73, no. 3 (2009): 200-14, http://search.proquest.com/docview/220694523/abstract.

21. Roger Baldwin et al., "Mapping the Terrain of Mid-Career Faculty at a Research University: Implications for Faculty and Academic Leaders," Change: The Magazine of Higher Learning 40, no. 5 (September 1, 2008): 46-55, https://doi.org/10.3200/CHNG.40.5.46-55.

22. Mathews, "Academic Mentoring Enhancing the Use of Scarce Resources."

23. Kimberly Buch et al., "Removing the Barriers to Full Professor: A Mentoring Program for Associate Professors," Change 43, no. 6 (December 11, 2011): 38-45, https://doi.org/10.1080/00091383.2011.618081.

24. Mara H. Wasburn, "Mentoring Women Faculty: An Instrumental Case Study of Strategic Collaboration," Mentoring \& Tutoring: Partnership in Learning 15, no. 1 (February 2007): 57-72, https://doi.org/10.1080/13611260601037389.

25. Peluchette and Jeanquart, "Professionals' Use of Different Mentor Sources at Various Career Stages."

26. I.J. Hetty van Emmerik, "The More You Can Get the Better: Mentoring Constellations and Intrinsic Career Success," Career Development International 9, no. 6/7 (2004): 578-94, http://search.proquest.com/ docview/219385429?pq-origsite=360link.

27. KerryAnn O'Meara and Nelly P. Stromquist, “Faculty Peer Networks: Role and Relevance in Advancing Agency and Gender Equity," Gender and Education 27, no. 3 (April 16, 2015): 338-58, https://doi.org/10.1080/0954 0253.2015.1027668.

28. Maxwell Awando et al., "Advancement of Mid-Career Faculty Members: Perceptions, Experiences, and Challenges," in Gender Transformation in the Academy, vol. 19, Advances in Gender Research (Bingley, UK: Emerald Group Publishing Limited, 2014), 199-220, http://www.emeraldinsight.com/doi/abs/10.1108/S1529212620140000019009; Modern Language Association of America, "Standing Still: The Associate Professor Survey," https://www.mla.org/About-Us/Governance/Committees/Committee-Listings/Professional-Issues/Committeeon-the-Status-of-Women-in-the-Profession/Standing-Still-The-Associate-Professor-Survey [accessed December 19, 2018]; Cheryl Geisler, Debbie Kaminski, and Robyn A. Berkley, "The 13+ Club: An Index for Understanding, Documenting, and Resisting Patterns of Non-Promotion to Full Professor," NWSA Journal 19, no. 3 (2007): 145-62, https://www.jstor.org/stable/40071233; Baldwin et al., "Mapping the Terrain of Mid-Career Faculty at a Research University."

29. Modern Language Association of America, "Standing Still," 24.

30. Susan K. Gardner and Amy Blackstone, "Putting in Your Time': Faculty Experiences in the Process of Promotion to Professor," Innovative Higher Education 38, no. 5 (November 2013): 411-25, https://doi.org/10.1007/ s10755-012-9252-x.

31. Geisler, Kaminski, and Berkley, "The 13+ Club," 156.

32. Maxwell Awando et al., "Advancement of Mid-Career Faculty Members"; Modern Language Association of America, "Standing Still"; Geisler, Kaminski, and Berkley, "The 13+ Club."

33. Modern Language Association of America, "Standing Still"; Baldwin et al., "Mapping the Terrain of Mid-Career Faculty at a Research University"; Maxwell Awando et al., "Advancement of Mid-Career Faculty Members."

34. Maxwell Awando et al., "Advancement of Mid-Career Faculty Members."

35. Geisler, Kaminski, and Berkley, "The 13+ Club."

36. William H. Walters, "Faculty Status of Librarians at U.S. Research Universities," Journal of Academic Librarianship 42, no. 2 (March 1, 2016): 161-71, https://doi.org/10.1016/j.acalib.2015.11.002.

37. Shaneka Morris, "ARL Annual Salary Survey 2016-2017," July 12, 2018, https://publications.arl.org/ARLAnnual-Salary-Survey-2016-2017/; American Community Survey, "Number of Higher Education Credentialed Librarians by Characteristic, 2000," Diversity Counts (March 29, 2007), www.ala.org/aboutala/offices/diversity/ diversitycounts/divcounts.

38. James T. Minor, "Faculty Diversity and the Traditions of Academic Governance," New Directions for In- 
stitutional Research 2013, no. 159 (July 1, 2014): 49-61, https://doi.org/10.1002/ir.20053; Ruben Gentry and Dorothy Stokes, "Strategies for Professors Who Service the University to Earn Tenure and Promotion," Research in Higher Education Journal 29 (September 2015), https://eric.ed.gov/?id=EJ1077941.

39. Department of Education, "Full-Time Faculty in Degree-Granting Postsecondary Institutions, by Race/ Ethnicity, Sex, and Academic Rank: Fall 2013, Fall 2015, and Fall 2016," Digest of Education Statistics (2017), https:// nces.ed.gov/programs/digest/d17/tables/dt17_315.20.asp [accessed December 11, 2018].

40. Geisler, Kaminski, and Berkley, "The 13+ Club."

41. Jerry A. Jacobs and Sarah E. Winslow, "Overworked Faculty: Job Stresses and Family Demands," ANNALS of the American Academy of Political and Social Science 596, no. 1 (November 1, 2004): 104-29, https://doi. org/10.1177/0002716204268185.

42. Darlene F. Zellers, Valerie M. Howard, and Maureen A. Barcic, “Faculty Mentoring Programs: Reenvisioning Rather than Reinventing the Wheel," Review of Educational Research 78, no. 3 (September 1, 2008): 552-88, http://www.jstor.org/stable/40071137; Wasburn, "Mentoring Women Faculty."

43. Maxwell Awando et al., "Advancement of Mid-Career Faculty Members." 